Goldschmidt 2021 Abstract

https://doi.org/10.7185/gold2021.3519

\section{Carbon in the deep Earth: The fate of magnesite in the lower mantle.}

\author{
LÉLIA LIBON ${ }^{1}$, GEORG SPIEKERMANN ${ }^{1,2}$, MELANIE \\ JUTTA SIEBER ${ }^{1,3}$, JOHANNES KAA ${ }^{4}$, SERENA \\ DOMINIJANNI $^{5}$, CHRISTIAN ALBERS $^{6}$, WOLFGANG \\ MORGENROTH ${ }^{1}$, NICOLE BIEDERMANN ${ }^{4}$, KAREN \\ APPEL $^{4}$, CATHERINE MCCAMMON $^{5}$, VLADIMIR $^{2}$ \\ RODDATIS $^{7}$, RACHEL HUSBAND ${ }^{8}$, KONSTANTIN \\ GLAZYRIN $^{8}$, LOUIS HENNET ${ }^{9}$ AND MAX WILKE ${ }^{1}$ \\ ${ }^{1}$ Universität Potsdam \\ ${ }^{2}$ ETH Zurich \\ ${ }^{3}$ Deutsches GeoForschungsZentrum \\ ${ }^{4}$ European XFEL \\ ${ }^{5}$ University of Bayreuth \\ ${ }^{6}$ TU Dortmund \\ ${ }^{7}$ GFZ German Research Centre for Geosciences \\ ${ }^{8}$ Deutsches Elektronen-Synchrotron \\ ${ }^{9}$ CNRS Orléans \\ Presenting Author: libon@uni-potsdam.de
}

Carbon's low solubility in mantle silicate indicates that it is mainly stored in accessory phases such as carbonates, diamonds or metal carbide [1]. However, our understanding of deep carbon storage in Earth's interior is still limited.

Carbonates may survive metamorphism and dehydration in the sub arc and reach the lower mantle. Although, the oxygen fugacity in the deep mantle may not favour the stability of carbonates, they have been discovered as inclusions in ultra-deep diamonds suggesting their presence at least in the transition zone [2]. Results of high-pressure experiments suggest that magnesite can be stable up to deep mantle pressure ( $~ 80 \mathrm{GPa}$ and $2500 \mathrm{~K})$ [3]. This observation makes magnesite, among carbonates, a suited candidate to be present in the deep Earth. However, our understanding of magnesite's stability with co-existing mantle silicate, such as bridgmanite, in the lower mantle is incomplete.

In order to address this issue, we conducted experiments using multi-anvil press and laser-heated diamond anvil cells (LHDAC) at conditions ranging from 25 to $68 \mathrm{GPa}$ and 1700 to 3000 $\mathrm{K}$. Experiments were designed to test sub-solidus reactions, melting, decarbonation and diamond formation in the magnesitebridgmanite system. Multi-anvil press experiments at $25 \mathrm{GPa}$ and temperatures below the mantle geotherm $(1700 \mathrm{~K})$ show formation of carbonate-silicate melt. In addition, bridgmanite and stishovite are formed, indicating incongruent melting of bridgmanite to stishovite, in accordance with [4]. Our LH-DAC data show presence of bridgmanite, ferromagnesite and stishovite as well as diamond. A melt phase could not be detected in situ at high temperature, however, presence of stishovite may indicate incongruent melting.

Our preliminary interpretation is that melting occurs in the magnesite-bridgmanite system at temperature below the mantle geotherm. Therefore, we suggest that if subducted carbonatebearing silicates survive down to the lower mantle, they will melt at conditions of the top of the lower mantle. Consequently, carbon is more likely present in its reduced form in the lower mantle (diamond or metal carbide).

[1] Dasgupta \& Hirschmann (2010) EPSL 298(1-2),1-13.

[2] Brenker et al. (2007) EPSL 260(1-2),1-9.

[3]Binck, et al. (2020) Physical Review Materials, 4(5),1-9.

[4]Litasov \& Shatskiy (2019) Geochemistry International, 57(9),1024-1033. 